\title{
North-West University conference: Evil spirits in Africa
}

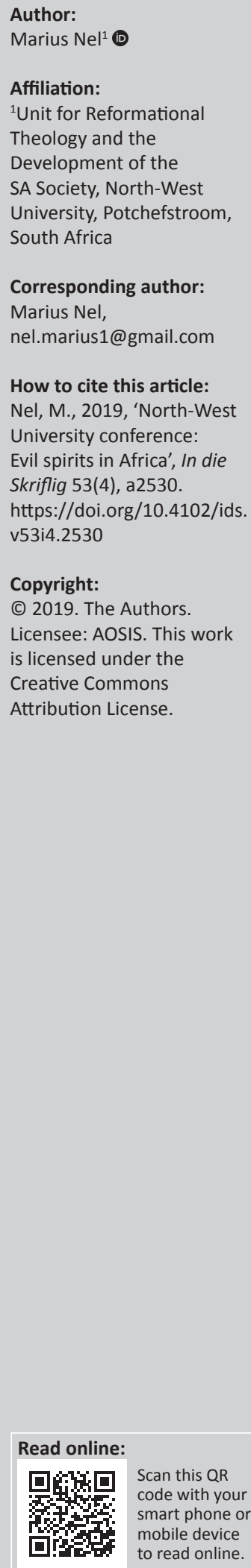

Most churches in Africa, whether connected with Western Christianity or a result of indigenous developments, have developed an African character based on a worldview related to African traditional religion. Many of these churches emphasise the working of the Spirit, bringing the confrontation to an African spirit-filled world where spirit-possession traditionally formed an essential element. They interpret ideas of the Holy Spirit in light of both a holistic spiritual world and the Bible. The spiritual world consists of good and evil spirits of which both influence what happens in the lives of people and communities. Ways to manipulate the spirits for the welfare of the community and the individual are integral to African religion.

It can be asserted that because of their focus on the spiritual world, these churches have been growing exponentially, leading to what has been described as a second African reformation. For them, the power of the Holy Spirit brings discontinuity to a continuous spirit world. The presence of the living God is experienced in the reality of the Holy Spirit's involvement in daily life, realising the imminence of God, God's intervention in human affairs and the power of God's Spirit. In Africa, this spiritual experience forms the motivation for the church's mission.

In 2018, the Faculty of Theology at the North-West University presented a seminar on the theme of rulers, authorities and powers in Africa. Several papers were read, highlighting some aspects of the role the spiritual world plays in African thinking and religion. Flip Buys argues that demonology should figure in the debate about the need to decolonise Reformed theological education in South Africa, as it represents a lacuna in Western theological endeavours. Many Western theologians seemingly operate without belief in the existence of the devil and evil forces. Buys believes that a Reformed hermeneutical study and interpretation of relevant biblical perspectives can enrich the lives of Christians. Francois Viljoen links to the emphasis on the assumed threats of cosmic powers and spiritual forces, and uses the Christ hymn in Colossians 1:13-20 to provide some useful perspectives. The hymn exalts Christ as superior to all other spiritual powers, as the mediator of creation, reconciler of the world and head of the church. Dependence on Christ alone, can set people free from ties to all the spiritual powers.

Another perspective is provided by Hannes Knoetze, who describes African spirituality as a holistic concept which emphasises, inter alia, the African family. Knoetze emphasises the role of the missional church and parents in the spiritual formation of their children. Naas Ferreira writes about the new formation of African Christianity as the 'Third Church' and argues that a historical reflection on the (original) temptation (Gn 3), can equip Christians and non-Christians in Africa for an appropriate defensive response against occult temptation. A last perspective is provided by Marius Nel, who discusses from a critical theological perspective the African Pentecostal narrative that is concerned with the solution of personal and societal problems interpreted in terms of the African view of rulers, authorities, evil powers, cosmic powers and spiritual forces. 